\title{
Há um direito a privacidade e intimidade absolutos na ordem jurídica e política democráticas contemporânea, notadamente em face de informações que visem o combate à corrupção ${ }^{1}$
}

\author{
There is an absolute right to privacy and intimacy in contemporary legal \\ and democratic political order, especially in the face of information aimed \\ to the fight against corruption?
}

ROGÉRIO GESTA LEAL

Desembargador do Tribunal de Justiça do Estado do Rio Grande do Sul

\begin{abstract}
RESUMO: A corrupção no Brasil e no mundo toma proporções estratosféricas hoje, causando danos em diversas áreas e segmentos sociais, notadamente nos Direitos Humanos e Fundamentais das pessoas mais pobres e com menores recursos de vida digna. Por outro lado, em face dos altos níveis de sofisticação, inteligência e organização sistêmica, os protagonistas destes cenários corruptivos muitas vezes logram êxito em suas ações, restando impunes em face dos déficits de ação preventiva e curativa dos poderes instituídos do Estado. Em face disto é que se deve perguntar se há um Direito Fundamental Individual à Privacidade absoluto a resguardar informações e dados pessoais em quaisquer circunstâncias.
\end{abstract}

Palavras-chaves: Direito Fundamental Individual à Privacidade. Corrupção. Direito Fundamental Social à Segurança.

\begin{abstract}
The corruption in Brazil and in the world today takes stratospheric proportions, causing damage in several areas and social segments, notably in Human and Fundamental Rights of the poorest and smaller features dignified life. Moreover, given the high levels of sophistication, intelligence and systemic organization, the protagonists of these corruptive scenarios often has succeed in their actions, leaving unpunished in the face of State deficits in preventive and curative action. On the face of it is that one must ask if there is a Fundamental Right to Individual Privacy absolute safeguard the information and personal data under any circumstances.

Keywords: Individual Fundamental Right to Privacy. Corruption. Social Fundamental Right to Security.
\end{abstract}

\section{NOTAS INTRODUTÓRIAS}

Há muito debate ainda hoje sobre o chamado Direito Fundamental à Privacidade e Intimidade, não só no Brasil, mas em todo o Ocidente, notadamente no que diz com os limites e blindagens possíveis a tais Direitos sob a perspectiva do combate à corrupção e aos crimes contra a Administração Pública.

Por outro lado, tem-se também afirmado que a informação e o conhecimento são pedras angulares da Democracia, por múltiplas razões, desde as que se relacionam com as condições e possibilidades de participação da cidadania na gestão dos interesses públicos (e seu controle), até o fato desta informação e conhecimento serem imperativos categóricos morais e jurídicos, per si, à Administração Pública e à Sociedade Democrática.

Pretendo neste texto fazer o enfrentamento desta questão, dando realce mais particular aos temas que envolvem a Lei Federal no 9.296/96, regulamentadora do inciso XII, do art. $5^{\circ}$, da Constituição Federal de 1988 - CF/88, determinando que a interceptação de comunicações telefônicas, de qualquer natureza, para prova em investigação criminal e em instrução processual penal, dependerá de ordem do juiz competente da ação principal, sob segredo de justiça, aplicando-se, ainda, à interceptação do fluxo de comunicações em sistemas de informática e telemática.

\section{QUAL O ESTADO DA ARTE DO DIREITO FUNDAMENTAL À PRIVACIDADE E INTIMIDADE NO BRASIL?}

O tema do Direito Fundamental à Privacidade e Intimidade não é novo no cenário filosófico, político e jurídico do Ocidente.

Há uma esfera de patrimônio imaterial do ser humano que veio sendo objeto de atenção jurídica 
progressiva no tempo, envolvendo exatamente outros níveis de existência que não o material e economicamente mensurável por regras de mercado produtivo, e que diz com a condição de ser no mundo deste sujeito e em suas relações afetivas, sexuais, familiares, etc.

Como quer Orlando de Carvalho, em tal situação o ser humano é recolocado no centro de ocupação dos ordenamentos jurídicos, dando-se o fenômeno que chama-com tantos outros autores, inclusive brasileiros - de Repersonalização do Direito, no qual a dimensão axiológica e ética das normas ganham mais relevo do que suas feições lógico-formais ${ }^{3}$.

O problema é a radicalização sobre os limites da proteção jurídica deste patrimônio imaterial, havendo quem compreenda, em Portugal, ser absoluto em todas as suas variantes, como quer Rabindranath de Souza:

\begin{abstract}
Os direitos de personalidade - entre os quais se insere o direito à intimidade da vida privada podem ser definidos como direitos subjectivos, privados, absolutos, gerais, extrapatrimoniais, inatos perpétuos, intransmissíveis, relativamente indisponíveis, tendo por objecto os bens e as manifestações interiores da pessoa humana, visando tutelar a integridade e o desenvolvimento físico e moral dos indivíduos e obrigando todos os sujeitos de direito a absterem-se de praticar ou de deixar de praticar actos que ilicitamente ofendam ou ameacem ofender a personalidade alheia sem que incorrerão em responsabilidade civil e/ou na sujeição às providências cíveis adequadas a evitar a consumação da ameaça ou a atenuar os efeitos da ofensa cometida ${ }^{4}$.
\end{abstract}

Veja-se que a Diretiva Europeia $n^{\circ}$ 95/46, de 24/10/1995, já dispunha que seus Estados membros devem garantir a tutela dos direitos e das liberdades fundamentais da pessoa física e particularmente o direito à vida privada, com especial atenção ao resguardo do tratamento de dados pessoais.

Na Itália, desde a Lei $n^{\circ} 675$, de 31/12/1996, o conceito de vida privada ganha relevo de tratamento, pois opera tal dispositivo forte regulação sobre o manejo de dados privados, a ponto de Alessandro Pace referir que con la legge 675/1996, quindi, è stata creata una nuova disciplina di fondamentale importanza che influenza lo svolgimento di ogni tipologia di attività, infatti, è praticamente impossibile individuare un'attività per l'effettuazione della quale non vengano utilizzati dati personali ${ }^{5}$. É interessante notar, todavia, a advertência que faz quanto as informações e dados atinentes à Administração Pública:

Tale diritto assurge quindi al rango di diritto fondamentale, non solo delle persone fisiche, ma anche di enti e persone giuridiche (fanno ovviamente eccezione gli Organi dello Stato e degli enti pubblici, nello svolgimento delle loro attività istituzionali, la cui attività pubblica esclude per definizione che si possa configurare l'esistenza di dati di natura personale, cui debba essere garantita la riservatezza) $)^{6}$.

E assim o é porque o que não se admite em termos jurídicos - e até éticos e morais - é a violação da intimidade em qualquer de suas nuances por parte de quem quer que seja em face de curiosidade patológica que muitos meios de comunicação e a excessiva exposição pública de determinadas pessoas fomentam no senso comum da população. Em outras palavras:

In generale, un fatto deve ritenersi privato (e rimanere riservato) quando la sua diffusione non ha alcuna utilità sociale. Quando, cioè, la collettività non può obiettivamente ricavare dalla sua conoscenza alcuna utilità. In assenza di questa, la divulgazione di un fatto privato cessa di servire l'interesse pubblico; e il diritto del singolo individuo alla riservatezza non può essere sacrificato senza il suo consenso ${ }^{7}$.

Acrescenta ainda o autor para o tema que estou tratando: Non possono invocare il diritto alla riservatezza lo stupratore e l'omicida, il truffatore e il medico abusivo, cosi come l'anonimo funzionario arrestato per corruzione. Qui il soggetto è trascinato al centro della scena pubblica unicamente a causa della gravità o eccezionalità dell'azione . $^{\text {. }}$

No caso do Brasil, a ordem constitucional elevou à condição de Direito Fundamental a Privacidade, nos termos do seu art. $5^{\circ}, \mathrm{X}$, assegurando a inviolabilidade da intimidade, da vida privada, da honra e da imagem das pessoas, prevendo o direito à indenização pelo dano material ou moral decorrente de sua violação.

Ao mesmo tempo, diz o Texto Político - como já referi - que é assegurado a todos o acesso à informação (art. $5^{\circ}, \mathrm{XIV}$ ), sendo que esta informação, sob qualquer forma, processo ou veículo, não sofrerá qualquer restrição, observado o disposto na Constituição, vedada ainda qualquer censura de natureza política, ideológica e artística. (art. 220 e $\S 2^{\circ}$ ).

No âmbito da infraconstitucionalidade, o Novo Código Civil brasileiro, em seu Livro I, Título I, Capítulo II, art. 11 e seguintes, regulamentou ainda mais o tema sob comento, destacando, dentre outras coisas: (a) o fato de que toda a pessoa tem direito ao nome, nele compreendidos o prenome e o sobrenome (art. 16); (b) ao fato de que, salvo se autorizadas, ou se necessárias à administração da justiça ou manutenção da ordem pública, a divulgação de escritos, a 
transmissão da palavra, ou a publicação, a exposição ou a utilização de imagem de uma pessoa poderão ser proibidas, a seu requerimento e sem prejuízo da indenização que couber, se lhe atingirem a honra, a boa fama ou a respeitabilidade, ou se destinarem a fins comerciais (art. 20); (c) ao fato de que a vida privada da pessoa natural é inviolável, e o juiz, a requerimento do interessado, adotará as providências necessárias para impedir ou fazer cessar ato contrário a esta norma (art. 21).

Vem daqui a ideia de que há determinadas qualidades que caracterizam a dignidade da pessoa, dentre elas, o respeito dos concidadãos (honra subjetiva e objetiva), o bom nome, a imagem e a reputação, e por tal razão devem ser observados ${ }^{9}$. Perez Luno lembra neste particular que se tratavam destas questões como o direito das pessoas à fama e reputação, bem como direito à tranquilidade do espirito e à solidão ${ }^{10}$.

É certo que o direito de privacidade não se confunde com o de Intimidade, representando este o núcleo mais reservado e indevassável da vida de determinada pessoa, em nada interessando à opinião pública o que faz ou deixa de fazer, pensar, sentir, fruir, etc., desde que não interferindo de forma violatória na vida de outras pessoas ${ }^{11}$. Tércio Sampaio Ferraz Jr. lembra muito bem que:

No que tange a intimidade, é a informação daqueles dados que a pessoa guarda para si e que dão consistência à sua pessoalidade - dados de foro íntimo, expressões de auto-estima, avaliações personalíssimas com respeito a outros, pudores, enfim dados que, quando constantes de processos comunicativos, exigem do receptor extrema lealdade e alta confiança, e que, se devassados, desnudariam a personalidade, quebrariam a consistência psíquica, destruindo a integridade moral do sujeito. Em termos do princípio da exclusividade, diríamos que esta é, nesses casos, de grau máximo ${ }^{12}$.

É interessante, todavia, como a Imagem tem um espectro amplo de potencial proteção, isto porque, como adverte Álvaro Barbosa, ela não pode ser restrita ao âmbito dos caracteres físicos de indivíduos, mas abarca o que se pode chamar de formas estáticas de representação (fotografia, pintura, fotograma, escultura, halografia), como também os dinâmicos (cinema, video). Para além disto, importa reconhecer que este direito à imagem se expande a determinados atributos construídos nas relações sociais, razão pela qual até uma caricatura - enquanto expressão artística que altera os traços físicos de alguém - pode conter elementos caluniosos, difamatórios ou injuriosos, os quais, somente em tais hipóteses e outras correlatas, e eventualmente, merecerá proteção curativa ou preventiva $^{13}$.

Aplica-se tal raciocínio também ao tema da Honra como bem juridicamente tutelado, aqui entendida enquanto conjunto de conceitos e juízos de determinada pessoa forjados no âmbito macrossocial (relações mais gerais mantidas no tecido social), e microssocial (relações parentais, afetivas, de trabalho, etc.), evidenciando o quanto as comunidades a que pertence o estimam, inclusive no que tange aos aspectos moral, intelectual, profissional.

Como quer Damásio de Jesus, a honra aqui se afigura como conjunto de atributos morais, físicos, intelectuais e demais dotes do cidadão, que o fazem merecedor de apreço no convívio social ${ }^{14}$.

Mas mesmo na esfera penal, entretanto, há divergências - ao menos no plano doutrinário - sobre o fato de que, sendo verdadeira a atribuição a determinado sujeito de um fato ofensivo à sua reputação, afigura-se possível, ou não, a caracterização da ofensa à sua honra, basta ver-se a posição de Tourinho Filho, fundado no que chama de Teoria da Notoriedade, ao referir que se o fato ofensivo à honra é notório, não pode o pretenso ofendido pretender defender o que ele já perdeu, e cuja perda caiu no domínio público, ingressando no rol dos fatos notórios ${ }^{15}$.

O Supremo Tribunal Federal do Brasil - STF, à unanimidade e em decisão de mérito envolvendo a lesão à imagem de atriz conhecida do público, entendeu sobre a matéria que:
Para a reparação do dano moral não se exige a ocorrência de ofensa à reputação do indivíduo. O que acontece é que, de regra, a publicação da fotografia de alguém, com intuito comercial ou não, causa desconforto, aborrecimento ou constrangimento, não importando o tamanho desse desconforto, desse aborrecimento ou desse constrangimento. Desde que ele exista, há o dano moral, que deve ser reparado, manda a Constituição, art. $5^{\circ}, \mathrm{X}^{16}$.

Em outras palavras, entendeu o STF que a caracterização do dano moral pelo uso indevido da imagem se dá em face do mero constrangimento e sentimento de desconforto e indignação do atingido ao ter sua imagem usada sem a devida concordância prévia, sobrevalorando o Direito Fundamental Individual à proteção da Imagem, eis que o interesse que se encontrava no lado oposto - da editora que veiculou a imagem -, era meramente comercial e privado, sem qualquer caráter público ou informativo social.

Mesmo que não se possa ainda extrair daqui posição definitiva da mais alta Corte do país envolvendo a questão discutida, sem sombra de dúvidas que há uma 
orientação hermenêutica geral ${ }^{17}$, até porque é conhecida a posição da jurisprudência nacional no que toca ao tratamento do dano moral decorrente de relações envolvendo patrimônios materiais, reconhecendo que o mero desconforto não geraria por sí só esta tipologia reparatória. Digo mais, talvez dificilmente ter-se-á posições absolutas no ponto, até em face das multiplas variáveis que podem surgir no contraste e ponderação entre direitos e interesses potencialmente conflitantes.

Por não ter a intenção de avançar sobremaneira nesta discussão, haja vista que a doutrina e casuística no Brasil já o fizeram no âmbito tanto do Direito Privado como do Público, gostaria apenas de dar destaque a uma das dimensões desta discussão que é o da Imagem da Pessoa Humana enquanto Sujeito de Direito, entendendo esta como direito em que a própria imagem de alguém não venha divulgada, exposta e publicizada sem o seu consenso, ou mesmo denegrindo o seu patrimônio imaterial (honra, privacidade, nome gentílico, sossego, etc.), violando a legislação reguladora da espécie. Em outras palavras, il termine immagine fa riferimento alla globale rappresentazione di un individuo agli occhi della collettività. In questo senso l'immagine coincide con quell'insieme di attributi della persona che la caratterizzano nei rapporti sociali o professionali ed è sinonimo soprattutto di reputazione e identità personale ${ }^{18}$.

Enquanto Direito Fundamental ele se encontra numa categoria de prerrogativa da pessoa humana passível de proteção administrativa e jurídica, a despeito de representar una categoria di diritti problematica, a causa della sua inerenza agli aspetti interiori della persona e non patrimoniali ${ }^{19}$.

$\mathrm{O}$ direito de imagem não se confunde, em face destes elementos, com direito intelectual, que opera no âmbito da comunicação e da arte em geral, tendo como foco de proteção o conhecimento e não a pessoa humana, a despeito de já se colocar, o primeiro, como produto de mercado também, basta ver o volume de negócios que representa o mundo da moda, cinema, televisão, revistas, etc., onde o marketing de publicidade e propaganda faz movimentar valores astronômicos.

De certa forma vige na cultura ocidental como um todo a premissa de que a possibilidade de exposição da imagem de quem quer que seja está relacionada, em primeiro lugar, ao consenso - tácito ou explícito ${ }^{20}$ - do exposto, desde que não viole disposição jurídica cogente sobre o tema. Mas tal consenso é sempre condição de possibilidade da exposição de imagem? Poderá haver questões de ordem pública que possam tensionar este Direito Fundamental?
A dotrina italiana tem uma boa abordagem deste tema:

In alcuni casi non è necessario acquisire il consenso della persona ritratta per poter esporre, riprodurre o fare un uso commerciale del ritratto: quando la riproduzione dell'immagine è giustificata dalla notorietà della persona ritratta, quando il ritratto viene riprodotto per fini scientifici, didattici o culturali, quando il ritratto si riferisce a fatti di interesse pubblico o svoltisi in pubblico, per fini di giustizia e di polizia ${ }^{21}$.

Vai nesta direção o tratamento dado pela jurisprudência norte-americana, na medida em que já teve oportunidade de decidir que a imprensa tem o direito de publicizar dados e informações pessoais de vítimas de estupro - conforme o caso Landmark Communications Inc. $\times$ Virgínia, $\mathrm{n}^{\mathrm{o}} 435$ US, 829, de 1978 -, bem como dar a conhecer publicamente o conteúdo de conversas telefônicas particulares obtidas ilicitamente - como no caso Bartnicki $\times$ Vopper, $\mathrm{n}^{\mathrm{o}}$ 121, S. Ct. 1753 , de $2001^{22}$.

Mas afinal, será que $A$ pessoa tem o direito de preservar a própria dignidade [...] mesmo ficticia, até contra ataques da verdade, pois aquilo que é contrário à dignidade da pessoa deve permanecer um segredo dela própria $^{23}$ ? Parece-me que não, isto porque há outros Direitos igualmente fundamentais que podem operar modulações neste Direito Individual, fundamentalmente os de natureza pública incondicionada - como é o caso dos crimes de corrupção enquanto gênero - que importam em interesse público indisponível.

E como dar tratamento àquelas situações em que, eventualmente, surjam aparentes ou reais tensões entre direitos e garantias privadas e públicas? O Supremo Tribunal Federal, na Relatoria do Ministro Gilmar Mendes, teve oportunidade de lembrar decisão da Corte Constitucional Alemã que pode apontar alguns caminhos de solução:

Considerou, inicialmente, o Tribunal que os valores constitucionais em conflito (liberdade de comunicação e os diritos de personalidade) configuram elementos essenciais da ordem democrático-liberal (freiheitlich demokratische ordnung) etabelecida pela Lei Fundamental, de modo que nenhum deles deve ser considerado, em princípio, superior ao outro. Na impossibilidade de uma compatibilização dos interesses conflitantes, tinha-se de contemplar qual haveria de ceder lugar, no caso concreto, para permitir uma adequada solução de colisão ${ }^{24}$.

Este debate se centra - direta ou indiretamente - junto ao tema complexo da Teoria do Direito e da 
Teoria do Discurso, partindo da lógica de que existem determinadas características constantemente exibidas em certas normas jurídicas (princípios), as quais se afiguram necessárias e suficientes para distingui-las de outras (regras), a saber: (a) as primeiras são normas particularmente importantes pelo fato de representarem valores fundantes e constitutivos do ordenamento, razão pela qual a relação que se impõe a eles é a aderência, enquanto as regras se obedecem; (b) os princípios têm graus de generalidade e vagueza muito amplos, com certa indeterminação, enquanto que as regras são normas que conectam consequências jurídicas a uma precisa fatispécie, associando uma modalidade deôntica (proibição, permissão ou obrigação) a certa conduta; (c) a aplicação dos princípios está condicionada a considerações de peso e importância, enquanto que as regras não poderiam ser operadas a partir desta lógica, mas deveriam ou não ser aplicadas ${ }^{25}$.

Mas quais são os fatores ou critérios que determinam ser uma norma mais ou menos importante que outra, com mais ou menos peso que outra? Essencial e tradicionalmente fatores de três tipos: (a) fatores atinentes à hierarquia da fonte (constitucional, infraconstitucional, internacional), tida como peso abstrato $^{26}$; (b) fatores atinentes à hierarquia axiológica acreditada pela cultura jurídica de referência ${ }^{27}$; (c) fatores associados às circunstâncias relevantes do caso concreto $^{28}$.

É certo que muitas regras jurídicas possuem, tanto no ordenamento positivado, como na cultura jurídica de referência, notável importância, tais quais as tipificações penais de condutas delituosas contra a vida (arts. 121 a 128, do Código Penal Brasileiro), configurando verdadeiras opções e cuidados axiológicos com determinados bens da vida, e, por isto, densificadores materiais dos princípios que sobre estes bens estabelecem diretrizes a serem seguidas.

Em face disto é que a forma subsuntiva de aplicação das regras (principalmente constitucionais) não se afigura tarefa fácil ou de apego irrestrito às dimensões gramaticais da lei escrita, eis que Subsumption, here as elsewhere in the Law, can be rather difficult and may require intermediate steps as well as further arguments of different kinds in order to justify these intermediate steps ${ }^{29}$. Ou seja, não raro, a atribuição de sentido que se dá às normas em face do caso concreto pode gerar situações de não adequação ou pertinência, impossibilitando sua aplicação - por isto todos os casos são de complexa solução. Em suas próprias palavras: A clareza de um caso, seja como for, não é algo tão simples assim. Quem afirma que uma decisão é clara, dá a entender que não há argumentos que dêem motivo a dúvidas sérias. No entanto, estes argumentos são sempre concebiveis ${ }^{30}$.

Alexy insiste com a tese de que nestes cenários há que se ter formas controláveis e públicas de procedimentos decisionais envolvendo a aplicação fundamentada do sistema normativo à solução de problemas intersubjetivos ou sociais judicializados. E que formas são estas? Uma delas é o chamado balanceamento de normas.

É o próprio autor que define o balanceamento como a terceira fase do teste de ponderação normativa que propõe à análise e decisão de casos judiciais: It has already been noted that balancing is the subject of the third sub-principle of the principle of proportionality. This is the principle of proportionality in the narrower sense, which concerns optimization relative to the legal possibilities at hand ${ }^{31}$, lembrando que o autor alemão compreende esta ponderação em três dimensões sucessivas e complementares, a saber: (a) adequação - ou subprincípio da idoneidade -, estando a exigir que toda a restrição aos direitos (notadamente aos fundamentais) seja idônea para o atendimento de um fim constitucionalmente legítimo, além do que os meios empregados devem ser instrumentalmente adequados para alcançar o fim almejado; (b) necessidade (ou subprincípio da indispensabilidade, do meio menos restritivo, do direito à menor desvantagem possível), no sentido de que dentre as várias medidas restritivas de direitos igualmente aptas para atingir o fim perseguido, a Constituição impõe que o legislador opte por aquela menos lesiva para os direitos envolvidos (certa proibição de excesso) ${ }^{32}$; (c) proporcionalidade em sentido estrito, no sentido de que uma restrição aos direitos é constitucional se pode ser justificada pela relevância da satisfação do princípio cuja implementação é buscada por meio da intervenção ${ }^{33}$.

Este balanceamento por certo que não é mecânico ou de sopesamento subjetivo de importância, validade ou vigência das normas do sistema jurídico, mas envolve juízos de valor na atribuição de sentido da norma ao caso concreto, a partir de parâmetros e diretrizes igualmente normativas, controladas e capazes de serem aferidas publicamente. Para além disto, como lembra Maniaci:

La seconda tesi che sosterrò è che nella Teoria dei diritti fondamentali Alexy, sebbene in modo non sempre sufficientemente chiaro, elabora un modello del bilanciamento tra principi secondo il quale le regole che determinano la precedenza di un principio sull'altro non soltanto sono defettibili, vista l'impossibilità di determinare tutte le proprietà rilevanti, ma sono, e devono sempre interpretarsi, 
come regole che impongono una relazione di precedenza 'relativa' soltanto ad alcuni tra i casi (generici) in relazione ai quali i due principi possono confliggere, relazione di precedenza che non è necessariamente valida per altri casi ${ }^{34}$.

No campo específico das regras jurídicas constitucionais, por exemplo, tem-se algumas particularidades que Alexy no texto refere, envolvendo o que chama do fenômeno da reserva legal dos sistemas normativos (statutory reservation), when a constitutional rights provision guarantees, in a first step, constitutional rights such as the right to life and to bodily integrity, and, in a second step, then empowers the legislature by means of a clause such as these rights can only be interfered with on a statutory basis ${ }^{35}$.

A ideia de fundo que está aqui é a de que se afigura mais do que possível, mas recomendado, no âmbito da ponderação e do balenceamento de normas em face do caso concreto, elaborar certa ordem hierárquica conjuntural entre os princípios que se encontram em tensão na casuística, tutelando, assim, um valor importante ao sistema jurídico que é a certeza do direito, entretanto, ele não é o único que demanda realização, pois ao seu lado está o valor de caráter pragmático relativo à eficiência social da prestação jurídica, igualmente importante e cuja realização pode eventualmente mitigar a realização do ideal de completude do ordenamento jurídico ${ }^{36}$.

Na decisão do Supremo Tribunal Federal anteriormente referida restou claro que dentre os bens jurídicos litigados (direito à informação e preservação da imagem), foi a privacidade e proteção da imagem que, no caso, se afigurou mais carente de proteção, até em face da finalidade meramente especulativa e invasiva, sem fins educativos, de precaução e de utilidade pública envolvidos na espécie para justificar a exposição sob comento.

Daí porque não se poder falar em segredo e sigilo nas atividades dos servidores públicos - com exceção, é claro, daquelas raríssimas hipóteses previstas por lei, e somente estas - razão pela qual tem fundamento legítimo a tese de Chequer:

A liberdade de expressão em sentido amplo também gozará do máximo de eficácia se a matéria, objeto dessa liberdade, estiver relacionada com uma pessoa pública, um funcionário público ou uma pessoa implicada em assuntos de interesse público. Haverá, nesses casos, portanto, um certo rebaixamento da tutela jurídica da honra dessas pessoas...

A difusão de conteúdos informativos verdadeiros, ainda que o seu conteúdo seja constrangedor, não pode ser considerada ofensiva à honra ${ }^{37}$.
Não bastasse isso, tem-se que ter em conta ainda a necessária leitura sistemática do ordenamento jurídico pátrio no ponto ${ }^{38}$. Neste sentido, o texto constitucional vigente está a confortar a proposta de viabilidade do controle ampliado das ações públicas, haja vista as disposições do art. $5^{\circ}, \mathrm{XXXV}$, tratando do princípio da inafastabilidade do controle judicial; do art. 102, I, $a$, II, $a$ e $b$, III, $a, b$ e $c$, e art.103, $\S 2^{\circ}$, que versam sobre o princípio da constitucionalidade dos atos estatais, ao dispor sobre os mecanismos assecuratórios da ordem constitucional e seus remédios/instrumentos protetivos.

Ganha mais força a tese de Chequer no sentido de que a honra não pode configurar obstáculo impeditivo de acesso à informação relacionada com investigações sobre cometimento de violações de direitos, eis que, nesses casos, o dano à honra da pessoa atingida pela matéria informativa ou pela expressão veiculada não se origina da veiculação da notícia, mas sim da própria conduta daquele que foi investigado, acionado em juizo ou preso ${ }^{39}$.

O que se tem de ter em mente, a partir do referido, é que, por mais que a norma constitucional - e o sistema jurídico como um todo - estabeleçam catálogos de direitos e garantias constitucionais referidas como autoaplicáveis, e disto não se tem dúvidas, o fenômeno de efetivação concretizante destes sempre contará com graus/medidas passíveis de mensuração, e estas, definitivamente, não estão dadas pela Carta Política, demandando do intérprete/aplicador atribuição de sentido racional e material às suas reivindicações, caso por caso (que inclusive pode tratar de interesse coletivo, difuso ou individual homogêneo), levando em conta o universo de variáveis que convergem a ele.

A partir destas premissas, cumpre verificar como elas podem auxiliar no processo de compreensão e aplicação das garantias individuais envolvendo o direito à privacidade e intimidade no caso particular daquelas situações que envolvem investigações criminais sobre atos de corrupção e crimes contra a Administração Pública que demandam eventual invasão desta privacidade e intimidade pela via da comunicação intersubjetiva.

\section{SÃO CONCILIÁVEIS OS DIREITOS FUNDAMENTAIS INDIVIDUAIS DA PRIVACIDADE E INTIMIDADE E O DA INVESTIGAÇÃO CRIMINAL QUE PRETENDA ACESSAR DADOS E INFORMAÇÕES ATINENTES A TAIS DIREITOS?}

Em termos históricos no Brasil, a ordem jurídica constitucional e infraconstitucional - sempre andou no 
sentido de proteger o Direito à Privacidade e Intimidade do cidadão, basta ver-se que a Constituição de 1824, em seu art.179, disciplinava:

Art. 179. A inviolabilidade dos Direitos Civis, e Politicos dos Cidadãos Brazileiros, que tem por base a liberdade, a segurança individual, e a propriedade, é garantida pela Constituição do Imperio, pela maneira seguinte. [...]

XXVII. O Segredo das Cartas é inviolavel. A Administração do Correio fica rigorosamente responsavel por qualquer infracção deste Artigo.

Não foi diferente com a Constituição de 1891, que em seu art.72, disciplinou que:

Art. 72. A Constituição assegura a brasileiros e a estrangeiros residentes no País a inviolabilidade dos direitos concernentes à liberdade, à segurança individual e à propriedade, nos termos seguintes:

$[\ldots]$

§18. É inviolável o sigilo da correspondência.

Na Constituição de 1934, em seu art. $113,8^{\circ}$, houve igualmente a proteção do sigilo da correspondência como declinação do direito à liberdade, enquanto que a Constituição de 1937, em seu art. 122, garantiu o direito à inviolabilidade do domicílio e de correspondência, salvas as exceções expressas em lei, tendo a Constituição de 1967 restaurado este sigilo como inviolável.

É somente na Emenda Constitucional $\mathrm{n}^{\mathrm{o}}$ 01, de 1969, que se teve a disposição normativa do art. 150, dizendo que: Art. 150. A Constituição assegura aos brasileiros e aos estrangeiros residentes no Pais a inviolabilidade dos direitos concernentes à vida, à liberdade, à segurança e à propriedade, nos termos seguintes: [...]. § $9^{\circ}$ São invioláveis a correspondência e o sigilo das comunicações telegráficas e telefônica.

Por fim, a Constituição de 1988, em seu art. $5^{\circ}$, incisos X e XII, dispôs que são invioláveis a intimidade, a vida privada, a honra e a imagem das pessoas, assegurado o direito a indenização pelo dano material ou moral decorrente de sua violação; bem como é inviolável o sigilo da correspondência e das comunicações telegráficas, de dados e das comunicações telefônicas, salvo, no último caso, por ordem judicial, nas hipóteses e na forma que a lei estabelecer para fins de investigação criminal ou instrução processual penal.

O sigilo, no inciso XII, do art. $5^{\circ}$, está referido à comunicação, no interesse da defesa da privacidade, e veja-se, a Constituição fala em sigilo da correspondência e das comunicações telegráficas, de dados e das comunicações telefônicas. Aqui a conjunção e une correspondência com telegrafia, seguindo-se uma vírgula e, depois, a conjunção de dados com comunicações telefônicas, evidenciando que há uma simetria proposital no ponto, pois o que se está regulando é a comunicação por correspondência e telegrafia, comunicação de dados e telefônica.

Por este conjunto de normas constitucionais sobre o tema pode-se facilmente verificar que a orientação liberal e ocidental do século XIX se manteve indene de modificações abruptas em sede de direitos individuais, inexistindo até o final do século XX, ao menos no Brasil, preocupações com a importância de se cotejar tais prerrogativas de foro intimo dos indivíduos com direitos públicos indisponíveis do Estado - e, portanto, da Sociedade - em ver atos ilícitos serem descobertos e punidos por quem os praticou, o que demandaria ponderação e balanceamento de interesses e direitos.

Note-se, antes de mais nada, que dos quatro meios de comunicação ali mencionados - correspondência, telegrafia, dados, telefonia - só o último se caracteriza por sua instantaneidade. Isto é, a comunicação telefônica só é enquanto ocorre, e, encerrada, não deixa vestígios - em tese - no que se refere ao relato das mensagens e aos sujeitos comunicadores. É apenas possível, a posteriori, verificar qual unidade telefônica ligou para outra. Pode-se dizer que a gravação de conversas telefônicas por meio de grampeamento é, pois, forma sub-reptícia de violação do direito ao sigilo da comunicação, mas, ao mesmo tempo, é a única tecnicamente conhecida de preservar a interlocução ocorrida. Por isso, no interesse público (investigação criminal ou instrução processual penal), é o meio de comunicação que exigiu, do constituinte, ressalva expressa, eis que os outros três não sofreram isto porque é possível realizar investigações e obter provas com base em vestígios que aqueles tipos de comunicação deixam: correspondências, telegramas, telex, telefax e recepções de mensagens telemáticas guardadas (individuais ou de redes sociais).

$\mathrm{O}$ que se tem de ter presente é que estas proteções constitucionais que se faz a tais direitos individuais não podem blindá-los do interesse público indisponível como é o caso da segurança pública e da investigação criminal -,

... pois o que se veda é, por exemplo, autorização judicial para interceptar correspondência, mas não para requerer busca e apreensão de documentos (e destas correspondências), ou seja, saber quais elementos de uma mensagem podem ser fiscalizados não se confunde com a questão de saber se e quando uma autoridade pode entrar no processo comunicativo entre dois sujeitos. São coisas distintas que devem ser examinadas distintamente. 
Assim, por exemplo, solicitar ao juiz que permita à autoridade acesso à movimentação bancária de alguém não significa pedir para interceptar suas ordens ao banco (sigilo da comunicação) mas acesso a dados armazenados (sigilo da informação) ${ }^{40}$.

E isto toma mais relevo ainda quando se vê em profusão comportamentos de ilicitude penal com alta sofisticação e inteligência - o crime organizado envolvendo o tráfico de drogas, a criminalidade econômica (lavagem de dinheiro, evasão de divisas, etc.), a microcriminalidade ordinária (fraudes em licitações e contratos públicos, a corrupção ativa e passiva, o peculato, etc.), desafiando os níveis de eficiência dos órgãos e processos de segurança que têm a competência de combater tais expedientes, e que não mais conseguem fazê-lo com o ferramental clássico investigativo do Código de Processo Penal brasileiro (interrogatório do art. 185 a 196; a acareação do art. 229 e 230; o depoimento do ofendido do art. 201; o depoimento das testemunhas do art. 202 a 225; a perícia do art. 158 a 184; o reconhecimento de pessoas e coisas do art. 226, 227 e 228; a busca e apreensão do art. 240 ao 250).

Por tais fatos é que têm surgido - inclusive internacionalmente - leis novas em face da nova criminalidade e suas feições de dinamismo, organização, inteligência e articulação sistêmica, tais como a que regulamenta a interceptação telefônica (Lei $\mathrm{n}^{\mathrm{o}}$ 9.034/95), notadamente sobre a utilização de meios operacionais à prevenção e repressão de ações praticadas por organizações criminosas, alguns meios de prova ali definidos, criando figuras como: (a) a utilização de ações controladas, que consiste em retardar-se a intervenção policial, mantendo-se acompanhamento e controle da ação praticada pelo que se supõe ser organização criminosa para concretização da medida legal, no momento mais eficaz do ponto de vista da formação de provas e fornecimento de informações (art. 20, II); (b) o acesso aos dados, documentos e informações fiscais, bancárias, financeiras e eleitorais, mediante autorização do juiz ( $\operatorname{art.} 2^{\circ}$, III); (c) a captação e interceptação ambiental de sinais eletromagnéticos, óticos ou acústicos, bem como seu registro e análise, mediante autorização judicial (art. $2^{\circ}$, IV); (d) a problemática utilização de agentes infiltrados (art. $\left.2^{\circ}, \mathrm{V}\right)$.

Ainda a Lei ${ }^{\circ} 9.296 / 96$, que regulamenta o inciso XII, parte final, do art. $5^{\circ}$, da Constituição Federal, tratando da interceptação de comunicações telefônicas de qualquer natureza para prova em investigação criminal e em instrução processual penal, alcançando o fluxo de comunicações em sistemas de informática e telemática.
Pode-se dar o exemplo também da Lei Complementar $n^{\circ} 105 / 01$, que dispõe sobre o sigilo das operações de instituições financeiras, prevendo, como meio de prova, a quebra de sigilo prevista em seu art. $1^{\circ}, \S 4^{\circ}$; de igual sorte as disposições do art. 53, da Lei $n^{\circ} 11.343 / 06$, inovando na criação de novas formas de captação da prova, tais como a figura dos agentes infiltrados e a ação retardada da autoridade policial.

Então se tem este quadro complexo no cotidiano das Sociedades contemporâneas: de um lado, disposições constitucionais e infraconstitucionais veiculadoras de Direitos e Garantias Fundamentais Individuais atinentes à proteção da privacidade, intimidade, personalidade, etc.; e de outro os deveres do Estado Democrático de Direito de garantir a ordem e a segurança a esta mesma Sociedade (art. 144, da CF/88), o que implica, dentre outras coisas, ser eficiente no desenvolvimento de suas políticas públicas preventivas e curativas (art. 37, caput, da CF/88).

É possível sim que surjam à efetivação destes comandos normativos situações de tensões ou conflitos entre direitos e interesses. E por que isto? Porque muitas vezes para se poder impor eficácia e eficiência às investigações e processos penais envolvendo determinados delitos complexos mister é que se utilize de mecanismos adequados às suas características e perfil de seus operadores. Mas isto deverá ser feito com critérios e justificativas muito claros e sob vigilância constante do Poder Judiciário - garante finalístico da legitimidade e legalidade destes procedimentos.

Basta ver o que demanda a Lei $n^{0}$ 9.296/96, anteriormente referida, à interceptação telefônica, de comunicação informática e telemática, tem prazo certo (15 dias, podendo ser renovada - art. $5^{\circ}$ ), não a admitindo nos casos em que: não houver indícios razoáveis da autoria ou participação em infração penal; a prova puder ser feita por outros meios disponíveis; o fato investigado constituir infração penal punida, no máximo, com pena de detenção (art. $2^{\circ}$ ), sendo exigido, como elemento habilitador da pretensão interceptiva, a situação objeto da investigação, inclusive com a indicação e qualificação dos investigados, salvo impossibilidade manifesta, devidamente justificada (§ único, do art. $2^{\circ}$ ).

Para além disto, exige-se que o pedido de interceptação de comunicação telefônica contenha a demonstração de que a sua realização é necessária à apuração de infração penal, com indicação dos meios a serem empregados (art. $4^{\circ}$ ), sendo que a gravação que não interessar à prova será inutilizada por decisão judicial, durante o inquérito, a instrução processual ou após esta, em virtude de requerimento do Ministério Público ou da parte interessada (art. $9^{\circ}$ ), afigurando-se 
crime realizar interceptação de comunicações telefônicas, de informática ou telemática, ou quebrar segredo da Justiça, sem autorização judicial ou com objetivos não autorizados em lei (art. 10).

Ou seja, há toda uma preocupação do sistema normativo em deixar claro que aqueles Direitos Fundamentais Individuais referidos acima continuam a contar com proteção de alta significação jurídica e política, e para que eles sejam atingidos é preciso a observância de condições muito especiais e controladas pelo próprio Estado. E está correta esta demarcação e tratamento, pois, caso contrário, estar-se-ia vivendo novamente e um regime de exceção e autoritário, como no período do Golpe Militar de 1964.

Mas como então tratar, no caso concreto, de possíveis conflitos/tensões destes Direitos/Interesses?

Nestes cenários há que se ter formas controláveis e públicas de procedimentos decisionais envolvendo a aplicação fundamentada do sistema normativo à solução de problemas intersubjetivos ou sociais judicializados. E que formas são estas?

Uma delas é o chamado balanceamento de normas preconizado por Robert Alexy, definindo-o como a terceira fase do teste de ponderação normativa que propõe à análise e decisão de casos judiciais: It has already been noted that balancing is the subject of the third sub-principle of the principle of proportionality. This is the principle of proportionality in the narrower sense, which concerns optimization relative to the legal possibilities at hand ${ }^{41}$, lembrando que ele compreende esta ponderação em três dimensões sucessivas e complementares, a saber: (a) adequação - ou subprincípio da idoneidade -, estando a exigir que toda a restrição aos direitos (notadamente aos fundamentais) seja idônea para o atendimento de um fim constitucionalmente legítimo, além do que os meios empregados deverem ser instrumentalmente adequados para alcançar o fim almejado; (b) necessidade (ou subprincípio da indispensabilidade, do meio menos restritivo, do direito à menor desvantagem possível), no sentido de que dentre as várias medidas restritivas de direitos igualmente aptas para atingir o fim perseguido, a Constituição impõe que o legislador opte por aquela menos lesiva para os direitos envolvidos (certa proibição de excesso) ${ }^{42}$; (c) proporcionalidade em sentido estrito, no sentido de que uma restrição aos direitos é constitucional se pode ser justificada pela relevância da satisfação do princípio cuja implementação é buscada por meio da intervenção ${ }^{43}$.

Este balanceamento por certo que não é mecânico ou de sopesamento subjetivo de importância, validade ou vigência das normas do sistema jurídico, mas envolve juízos de valor na atribuição de sentido da norma ao caso concreto, a partir de parâmetros e diretrizes igualmente normativas, controladas e capazes de serem aferidas publicamente ${ }^{44}$. Como lembra Maniaci:

La seconda tesi che sosterrò è che nella Teoria dei diritti fondamentali Alexy, sebbene in modo non sempre sufficientemente chiaro, elabora un modello del bilanciamento tra principi secondo il quale le regole che determinano la precedenza di un principio sull'altro non soltanto sono defettibili, vista l'impossibilità di determinare tutte le proprietà rilevanti, ma sono, e devono sempre interpretarsi, come regole che impongono una relazione di precedenza 'relativa' soltanto ad alcuni tra i casi (generici) in relazione ai quali i due principi possono confliggere, relazione di precedenza che non è necessariamente valida per altri casi ${ }^{45}$.

No campo específico das regras jurídicas constitucionais, por exemplo, tem-se algumas particularidades que Alexy no texto refere, envolvendo o que chama do fenômeno da reserva legal dos sistemas normativos (statutory reservation), when a constitutional rights provision guarantees, in a first step, constitutional rights such as the right to life and to bodily integrity, and, in a second step, then empowers the legislature by means of a clause such as [t]hese rights can only be interfered with on a statutory basis ${ }^{46}$.

No caso da Constituição Brasileira de 1988 têm-se algumas situações mais claras em que a própria Carta Política estabelece direitos fundamentais e os restringe ao mesmo tempo, ex vi o disposto no art. $5^{\circ}$, XVI, ao garantir o direito de reunião, mas ao mesmo tempo flexibilizando-o em face do cotejado com o disposto no art. 136, $\S 1^{\circ}$, I, a (Estado de Defesa), e art. 139, IV (Estado de Sítio, em que poderá haver restrições a este direito de reunião.

O sistema jurídico precisa conviver com esta instabilidade material que a reserva legal cria, mesmo que aparentemente paradoxal em face das expectativas que se tenham gerado pela aparência de segurança e confiabilidade que ele igualmente deve garantir. O problema por vezes é como lidar com isto, pois, a meu juízo, não é uma ferramenta como a do círculo hermenêutico (Gadamer e alguns de seus sedizentes seguidores), como tal, que vai ajudar muito, pelo simples fato de que ela não diz nada sobre os critérios de afirmação ou rejeição da hipótese de interpretação/aplicação que se poderia usar nestes casos. Essa pergunta só pode ser decidida com base em argumentos. Isso já demonstra que a teoria do círculo hermenêutico não pode substituir uma teoria da argumentação jurídica ${ }^{47}$. Vai mais longe o autor, e com ele concordo: 
Por um lado, para compreender uma norma, é necessário compreender o sistema de normas ao qual ela pertence; de outra sorte, não é possível compreender um sistema de normas sem compreender as normas específicas pelas quais o sistema é constituído. Novamente, encontramos, aqui, apenas a formulação de um problema, mas nenhum critério é oferecido para sua solução. O problema reside na criação de unidade ou de coerência. Essa é a tarefa da argumentação sistêmica ${ }^{48}$.

A ideia de fundo que está aqui é a de que se afigura mais do que possível, mas recomendado, no âmbito da ponderação e do balenceamento de normas em face do caso concreto, elaborar certa ordem hierárquica conjuntural entre os princípios que se encontram em tensão na casuística, tutelando assim um valor importante ao sistema jurídico que é a certeza do direito, entretanto, ele não é o único que demanda realização, pois ao seu lado está o valor de caráter pragmático relativo à eficiência social da prestação jurídica, igualmente importante e cuja realização pode eventualmente mitigar a realização do ideal de completude do ordenamento jurídico.

A questão, pois, que se coloca, é se esta metodologia de abordagem da norma jurídica, em face dos casos concretos e dos procedimentos que se fomentam à decisão judicial, apresentam ou não níveis de racionalidade pública e controláveis pela via da argumentação/comunicação jurídica.

Alexy responde positivamente, dando um exemplo ocorrido na Corte Constitucional Alemã - e que serve para o Brasil-, quando tratou do tema envolvendo a obrigatoriedade das indústrias produtoras de tabaco colocarem em seus produtos fumígeros advertências sobre os riscos à saúde que estes representam. Concluiu Alexy que tal obrigação poderia ser aferida em face da ponderação de interesses existentes na espécie, utilizando a lei do balenceamento, chegando à conclusão de que, primeiro, não haveria qualquer conflito intransponível entre a regulação estatal no âmbito da produção e venda daqueles produtos e a liberdade de profissão, atividade industrial ou comercial; segundo, sequer existiria excessiva intervenção pública na ordem econômica, haja vista a proteção de um bem jurídico vida/saúde - que tem maior peso e importância do que outro bem jurídico tutelado pela mesma Constituição, que é a liberdade de produção e comércio de bens lícitos.

As regras do discurso racional prático, em tal acepção, não prescreveriam premissas a partir das quais partiram as partes discursantes, mas tão somente definiriam um processo de tomada de decisão, no qual há incertezas quanto o que deve tomar parte da base da decisão - enquanto que nas regras do discurso racional jurídico haverá estas bases (direitos fundamentais, constitucionais, etc. $)^{49}$-, e nem todos os passos estariam prescritos de forma clara e absoluta.

Isto não pode, entretanto, levar a teoria do discurso para um campo de relativismos absolutos, isto porque a investigação discursiva, ainda que não leve à certeza matemática e absoluta, oportuniza pelo menos a sair do campo da mera opinião e da crença subjetiva, viabilizando-se, então, o conceito de adequação discursiva relativa, proposta por Alexy, isto tanto para o sopesamento de princípios como de regras jurídicas no âmbito de suas aplicações práticas ${ }^{50}$.

Por tais razões Alexy sustenta, com o que concordo, que a relação entre a teoria da argumentação jurídica com a argumentação prática geral não pode ser concebida a partir da ideia de subordinação da primeira em relação à segunda (sempre que houver casos em que a solução não possa ser derivada conclusivamente da lei, o discurso jurídico não passa de um discurso prático geral por trás de uma fachada jurídica); tampouco pode estabelecer relação de suplementação de uma em relação à outra (a argumentação jurídica só poderia ir até uma parte do caminho, chegando a um ponto em que os argumentos especificamente jurídicos não seriam mais disponíveis, intervindo a partir daí a argumentação prática em geral); mas que deve haver uma relação de integração entre estas duas argumentações, no sentido de que argumentos jurídicos e práticos em geral se combinem em todos os níveis, aplicando-se conjuntamente ${ }^{51}$

O mesmo raciocínio poderia se aplicar ao tema que estou propondo à discussão, pois a segurança e a ordem públicas (Direitos Fundamentais Sociais) precisam conviver harmonicamente com a garantia da intimidade e privacidade dos cidadãos (Direitos Fundamentais Individuais), pois não se vai resolver esta equação com argumentos maniqueístas ou fundamentalistas de um lado ou outro, porque os níveis de insegurança e desordem públicas violam talvez mais direitos e garantias individuais do que os que se poderia proteger através de mecanismos e ferramentas eficazes ao combate dos diferentes tipos de criminalidade existentes hoje.

A verdade é que tanto a macro como a microcriminalidades se valem de grandes e arquitetadas estruturas organizacionais e de inteligência, criando inúmeras situações de difícil investigação e apuração em termos de responsabilidade civil e penal, constituindo empresas fantasmas, laranjas, lavagem de dinheiro através de fórmulas jurídicas e contábeis de aparente legalidade, etc., valendo-se até de figuras como a compliance para transferir autorias de atos 
corruptivos e ilícitos, o que demanda modelos de investigação igualmente aprimorados.

Tais modelos, a despeito disto, não podem violar direitos e garantias constitucionais e infraconstitucionais da cidadania, sob pena de caracterizar-se ilegítima e ilícita a persecução penal, aliás, como tem dito o Supremo Tribunal Federal:

A prova ilícita, entre nós, não se reveste da necessária idoneidade jurídica como meio de formação do convencimento do julgador, razão pela qual deve ser desprezada, ainda que em prejuízo da apuração da verdade, no prol do ideal maior de um processo justo, condizente com o respeito devido a direitos e garantias fundamentais da pessoa humana, valor que se sobrelevam, em muito, ao que é representado pelo interesse que tem a sociedade numa eficaz repressão aos delitos. É um pequeno preço que se paga por viver-se em Estado de Direito Democrático. A justiça penal não se realiza a qualquer preço. Existem, na busca da verdade, limitações impostas por valores mais altos que não podem ser violados, ensina Heleno Fragoso, em trecho de sua obra Jurisprudência Criminal, transcritas pela defesa ${ }^{52}$.

O problema é saber qual a natureza da ilicitude referida e proibida pelo sistema jurídico brasileiro! Diz com a forma processual de sua obtenção ou também à materialidade de seu conteúdo? Podem-se admitir balanceamentos e ponderações conjunturais sobre esta natureza em face de circunstâncias fáticas e operacionais envolvendo a complexidade do objeto de prova que se está a buscar?

É interessante a assertiva de Avolio quando lembra que, numa fase preambular, onde o tema das provas ilícitas mereceu, pela primeira vez, a atenção dos juristas, o condicionamento aos dogmas do 'livre convencimento' e da 'verdade real', fazia com que um eventual balanceamento dos interesses em jogo pendesse, inequivocamente, em favor do principio da investigação da verdade, ainda que baseado em meios não necessariamente regulares ${ }^{53}$. O Supremo Tribunal Federal já se manifestou a respeito, ao dizer que:

Não há no sistema constitucional brasileiro, direitos ou garantias que se revistam de caráter absoluto, mesmo porque razões de relevante interesse público ou exigências derivadas do princípio de convivência das liberdades legitimam, ainda que excepcionalmente, a adoção, por parte dos órgãos estatais, de medidas restritivas das prerrogativas individuais ou coletivas, desde que respeitados os termos estabelecidos pela própria Constituiçã $0^{54}$.
Delação anônima. Comunicação de fatos graves que teriam sido praticados no âmbito da administração pública. Situações que se revestem, em tese, de ilicitude (procedimentos licitatórios supostamente direcionados e alegado pagamento de diárias exorbitantes). A questão da vedação constitucional do anonimato ( $C F$, art. $5^{\circ}, \mathrm{IV}$, 'in fine'), em face da necessidade ético-jurídica de investigação de condutas funcionais desviantes. Obrigação estatal, que, imposta pelo dever de observância dos postulados da legalidade, da impessoalidade e da moralidade administrativa (CF, art. 37, 'caput'), torna inderrogável o encargo de apurar comportamentos eventualmente lesivos ao interesse público. Razões de interesse social em possível conflito com a exigência de proteção à incolumidade moral das pessoas $\left(\mathrm{CF}\right.$, art. $\left.5^{\circ}, \mathrm{X}\right)$. O direito público subjetivo do cidadão ao fiel desempenho, pelos agentes estatais, do dever de probidade constituiria uma limitação externa aos direitos da personalidade? Liberdades em antagonismo. Situação de tensão dialética entre princípios estruturantes da ordem constitucional. Colisão de direitos que se resolve, em cada caso ocorrente, mediante ponderação dos valores e interesses em conflito ${ }^{55}$.

Da mesma sorte o Superior Tribunal de Justiça em épocas mais passadas já insistia com a tese de que a gravação de conversa por um dos interlocutores não é interceptação telefônica, sendo lícita como prova no processo penal, isto porque, pelo já referido Princípio da Proporcionalidade, as normas constitucionais se articulam num sistema, cuja harmonia impõe que, em certa medida, tolere-se o detrimento a alguns direitos por ela conferidos, no caso, o direito à intimidade ${ }^{56}$.

Mais especialmente num caso que envolvia a administração penitenciária, o STF, com fundamento em razões de segurança pública, sustentou que esta pode, excepcionalmente, proceder à interceptação da correspondência remetida pelos sentenciados, eis que a cláusula da inviolabilidade do sigilo epistolar não pode constituir instrumento de salvaguarda de práticas ilícitas ${ }^{57}$. Tal excepcionalidade, por certo, deverá ser justificada e fundamentada com argumentos sólidos e convincentes da necessidade, proporcionalidade e intensidade da medida, sempre em face do caso concreto.

Há outro argumento forte nesta tese, tratada por Fernando Capez, por exemplo, a saber, o do princípio da proporcionalidade pro reo, a partir da justificativa de que o princípio que veda as provas obtidas por meios ilícitos não pode ser usado como escudo destinado a perpetuar condenações injustas. Entre aceitar uma prova vedada, apresentada como único meio de comprovar a inocência de um acusado, e permitir 
que alguém, sem nenhuma responsabilidade pelo ato imputado, seja privado injustamente de sua liberdade, a primeira opção é, sem dúvida, a mais consentânea com o Estado Democrático de Direito e a proteção da dignidade humana ${ }^{58}$.

\section{CONSIDERAÇÕES FINAIS}

O que se tem de ter em mente, a partir do referido, é que, por mais que a norma constitucional estabeleça catálogos de direitos e garantias constitucionais referidas como autoaplicáveis, e disto não se tem dúvidas, o fenômeno de efetivação concretizante destes sempre contará com graus/medidas passíveis de mensuração, e estas, definitivamente, não estão dadas pela Carta Política, demandando do intérprete/ aplicador atribuição de sentido racional e material às suas reivindicações, caso por caso (que inclusive pode tratar de interesse, coletivo, difuso ou individual homogêneo), levando em conta o universo de variáveis que convergem a ele, daí porque Schauer insistir na tese de que:

\begin{abstract}
When critics like Habermas accuse the balancing process of being irrational, however, it appears that what they mean is 'unconstrained'. It is not as if we normally think of other open-ended decisionmaking approaches as irrational just because they involve some likelihood of variability. A pure but sophisticated act utilitarianism, for example, may impose too many demands on decision-makers, and may involve widely divergent evaluations of the relative utilities involved, but it is hard to see it as irrational ${ }^{59}$.
\end{abstract}

De qualquer sorte, sempre, The rationality of an inferential structure essentially depends on the question of whether it connects premises that, again, can be justified. Mas justificadas estas premissas a partir de que razões e fundamentos válidos? É Alexy que responde: The commensurability of the assessments on both sides of the balance is granted if the discourse is conducted on the basis of a common point of view: the point of view of the constitution ${ }^{60}$.

Desta forma, uma teoria do discurso jurídico que tem a intenção de satisfazer a pretensão à legitimidade da ordem jurídica, há de dar uma resposta à questão acerca de como decisões jurídicas sucedem vinculadas a decisões institucionais precedentes e como podem ser fundamentadas racionalmente ${ }^{61}$.

Fala Alexy, por certo, da vinculação que decisões jurídicas devem ter com outras - institucionais/ parlamentares/constitucionais - que servem de demarcação originária à legitimação democrática da ação judicial $^{62}$. A necessária fundamentação que se exige pela via do discurso jurídico igualmente está demarcada pelos significados e sentidos encetados pelo sistema normativo vigente, que a despeito de em constante mutação, conta com referências, procedimentos e instâncias deliberativas regulares que precisam ser observadas sob pena de dar-se vezo a imposições autoritárias, veiculadas pela assertiva de que La norma è dunque la volontà della legge come pensata da colui che in concreto decide, influenzato dal contesto sociale e giuridico in cui si trova ad operare ${ }^{63}$.

E isto ocorre por uma razão muito simples, a saber, pelo fato de que uma teoria coerencial do direito não pode resolver sozinha o problema da aplicação racional do direito. Assim como regras não podem se aplicar a elas mesmas, um sistema não pode produzir ele próprio a resposta correta. Para tanto, são necessários pessoas e procedimentos ${ }^{64}$. Todavia, estas pessoas e procedimentos precisam, por sua vez, estar ancorados em sistemas normativos que possuem caráter fundamentalmente deontológico, regulando o contexto vital dos cidadãos de uma comunidade jurídica concreta.

Daí a conclusão de Alexy - diferente de Habermas ${ }^{65}$ -, no sentido de que este caráter deontológico do sistema normativo (princípios e regras jurídicas) não implica absolutos, podendo ser compreendido como constituído, dentre outras coisas, por mandados de otimização ${ }^{66}$, utilizando na ponderação e balanceamento dos princípios em face de casos concretos relações de precedência condicionada que vão indicar as condições na presença das quais um princípio prevalecerá sobre o outro, ou seja, le condizioni in presenza delle quali un principio precede l'altro costituiscono il presupposto di fatto di una regola che esprime la conseguenza giuridica del principio prevalente ${ }^{67}$.

No caso do Direito Penal e Processual Penal, como assevera Maria Carnauba, não é correto que um Estado se proponha a promover a justiça e permaneça sistematicamente deixando impunes crimes de alto poder lesivo para a sociedade, sob o argumento de que o modo de coleta das provas foi acintoso à privacidade do criminoso. [...] A questão é preocupante quando se sabe que, em determinados casos, somente pela ingerência na esfera de privacidade alheia é possível a obtenção de provas em alguns delitos. Tome-se como exemplo o caso dos crimes que trazem prejuizos ao erário público ${ }^{68}$.

Volto a dizer, mister é que se tenha, sempre, bem ponderadas/balanceadas as razões de justificação e fundamentação de medidas solucionadoras in concreto das tensões entre os Direitos, Garantias e Interesses que discuti neste texto, sempre de forma pública 
e transparente, com o maior nível de interlocução emancipada entre todos os interessados ao deslinde dos problemas envolvidos.

\section{REFERÊNCIAS}

ALEXY, Robert. A argumentação jurídica como discurso racional. In: TEIXEIRA, Anderson Vichinkeski.

A theory of legal argumentation: the theory of rational discourse as theory of legal justification. In: Ratio Juris. New York: Hammel, 2010. v. 37.

Os direitos fundamentais e a democracia no paradigma procedimental do direito de Jürgen Habermas. In FRANKENBERG, Günter; MOREIRA, Luiz. Jürgen Habermas: 80 anos. Rio de Janeiro: Lúmen Júris, 2009.

Teoria da argumentação jurídica: a teoria do discurso racional como teoria da justificação jurídica. São Paulo: Landy, 2001.

Teoría de los derechos fundamentales. Madrid: Centros de Estudios Constitucionales, 2000.

The construction of constitutional rights. In: Law \& Ethics of Human Rights, Berkeley: Berkeley Electronic Press, v, 4, n. 1, article 2, 2010

ANDRONICO, Alberto. Ermeneutica e Diritto da Wilhelm Dilthey ed Emilio Betti. In: Spicchi di Novecento, a cura di Bruno Montanari. Roma: Giappichelli, 2008.

AVÓLIO, Luiz Francisco Torquato. Provas ilícitas: interceptações telefônicas clandestinas. São Paulo: Revista dos Tribunais. 2003.

BARBOSA, Álvaro Antônio do Cabo. Direito à própria imagem. Aspectos fundamentais. São Paulo: Saraiva, 1989.

BARROS, Suzana de Toledo. O princípio da proporcionalidade e o controle de constitucionalidade das leis restritivas de direitos fundamentais. Brasília: Brasília Jurídica, 2000.

BITENCOURT, Cezar Roberto. Código penal comentado. São Paulo: Saraiva, 2010.

BÖCKENFÖRDE, Ernst-Wolfgang. Staat, Verfassung, Demokratie, 190. 1991.

CANARIS, Wilhelm Canaris. Pensamento sistemático e conceito de sistema na ciência do direito. Lisboa: Fundação Calouste Gulbenkian, 1996.

CAPEZ, Fernando. Curso de processo penal. São Paulo: Saraiva, 2008.

CARNAUBA, Maria Cecília Pontes. Prova ilícita. São Paulo: Saraiva, 2000.

CARVAlHO, Márcia Haidée Porto de. A defesa da honra e o direito à informação. Florianópolis: Letras Contemporâneas, 2002.

CARVAlHO, Orlando de. Para uma teoria geral da relação jurídica. Coimbra: Centelha, 1981.

CASTRO, Sandro. Il danno all'immagine. Roma: Giappichelli Editore, 2013.

CELANO, Bernardo. Dialettica della giustificazione pratica. Torino: Giappichelli, 2008

CHEQUER, Cláudio. A liberdade de expressão como direito fundamental preferencial prima facie. Rio de Janeiro: Lúmen Júris, 2011.

FERRAZ JR., Tércio Sampaio. Sigilo de dados: o direito à privacidade e os limites à função fiscalizadora do Estado.

FRANÇA, Rubens Limongi. Instituições de direito civil. São Paulo: Saraiva, 1999.

GOMES FILHO, Antonio Magalhães. Direito à prova no processo penal. São Paulo: RT, 1997.
GOMES, Orlando. Introdução ao direito civil. Rio de Janeiro: Forense, 2000.

GRIFFIN, Stephen. American Constitutionalism: from theory to politics. Princeton: Princeton University Press, 1996.

GRINOVEER, Ada Pellegrini. Liberdades públicas e processo penal: as interceptações telefônicas. São Paulo: Revista dos Tribunais, 1982

GRINOVER, Ada Pellegrine; FERNANDES, Antonio Scaranze; GOMES FILHO, Antonio Magalhães. As nulidades no processo penal. São Paulo: Revista dos Tribunais, 2001.

GUASTINI, Ricardo. Le fonti del diritto e l'interpretazione. Milano: Giuffrè, 1993.

HABERMAS, Jürgen. Between Facts and Norms: contributions to a discourse theory of law and democracy. William Rehg trans, Polity Press, 1996.

JESTAEDT, Matthias. Die Abwägungslehre - ihre Stärken und ihre Schwächen. In: Staat im Wort: Festschrift für Josef Isensee 253, 260, 262-63, 275 (Otto Depenheuer, Markus Heintzen, Matthias Jestaedt, \& Peter Axer eds., 2007).

JESUS, Damásio. E. de. Direito penal: parte especial: dos crimes contra a pessoa. Dos crimes contra o patrimônio. São Paulo: Saraiva, 2006

KLEMENT, Jan Henrik. Vom Nutzen einer Theorie. Die alles erklärt, 63. Juristenzeitung 756, 760 (2008).

LEAL, Rogério Gesta. A decisão judicial: elementos teóricoconstitutivos à efetivação pragmática dos Direitos Fundamentais. Chapecó: UNOESC, 2012

O Estado-Juiz na democracia contemporânea: uma perspectiva procedimentalista. Porto Alegre: Livraria do Advogado, 2007.

LEEBAW, Bronwyn. Judging State-sponsored violence, imagining political change. New York: Cambridge University Press, 2012.

LUÑO, Antonio Henrique Pérez. Derechos humanos, estado de serecho y constitución. Madrid: Tecnos, 1999.

MANIACI, Giorgio. Note sulla teoria del bilanciamento di Robert Alexy. In: Rivista Diritto \& Questioni Pubbliche, Palermo: Università degli Studi di Palermo, v. 2. ago. 2002.

MENGONI, Luiggi. Ermeneutica e dogmatica giuridica. Milano: Giuffrè, 2006.

OLIVEIRA, Elton Somensi de Oliveira. (Orgs.). Correntes contemporâneas do pensamento jurídico. São Paulo: Manole, 2010.

PACE, Alessandro. Metodi interpretativi e costituzionalismo. Quaderni Costituzionali, Rivista Italiana di Diritto Costituzionale, n. 1, aprile 2001. ISSN: 0392-6664.

PONTES DE MIRANDA, Francisco Cavalcanti. Tratado de direito privado. Direito de personalidade. Direito de família. Rio de Janeiro: Borsoi, 1955.

POSCHER, Ralf. Einsichten, Irrtümer und Selbstmißverständnisse der Prinzipientheorie. In: Die Prinzipientheorie der Grundrechte: studien zur grundrechtstheorie Robert Alexys. 59, 65, 70 (Jan-R. Sieckmann ed., 2007).

PROSPERI, Massimo. La tutela dell 'immagine. Roma: Giappichelli Editore, 2012.

SCHAUER, Francisco. Le regole del gioco. Un'analisi filosofica delle decisioni prese secondo regole nel diritto e nella vita quotidiana. Bologna: Il Mulino, 2009.

SCHAUER, Frederick. The nature of customary law: legal, historical and philosophical perspectives. New York: Amanda Perreau-Saussine \& James Bernard Murphy eds., 2007.

SCHLINK, Bernhard. Der Grundsatz der Verhältnismäßigkeit. In: Festschrift 50 Jahre Bundesverfassungsgericht 445, 460 (Peter Badura \& Horst Dreier eds., 2001). 
SILVA, Paulo Napoleão Nogueira da. Curso de direito constitucional. Rio de Janeiro: Forense, 2009.

SOUZA, Rabindranath Capelo de. A constituição e os direitos de personalidade. In: MIRANDA, Jorge. (Coord.). Estudos sobre a constituição. Lisboa: Petrony, 1978. v. 2.
TARELLO, Giovanni. Interpretazione della legge. Roma: Giuffrè, 2010.

TOURINHO FILHO, Fernando da Costa. Processo penal. São Paulo: Saraiva, 2007. v. 4.

\section{NOTAS}

1 Este artigo é o resultado de pesquisas feitas junto ao Centro de Direitos Sociais e Políticas Públicas, do Programa de Doutorado e Mestrado da Universidade de Santa Cruz do Sul-UNISC, e vinculado ao Diretório de Grupo do CNPQ intitulado Estado, Administração Pública e Sociedade, coordenado pelo Prof. Titular Dr. Rogério Gesta Leal, bem como decorrência de projeto de pesquisa intitulado Patologias corruptivas nas relações entre estado, adminstração pública e sociedade: causas, consequências e tratamentos.

2 Rogério Gesta Leal é Desembargador do Tribunal de Justiça do Estado do Rio Grande do Sul, Doutor em Direito. Prof. Titular da UNISC. Professor da UNOESC. Professor Visitante da Università Túlio Ascarelli - Roma Trè, Universidad de La Coruña - Espanha, e Universidad de Buenos Aires. Professor da Escola Nacional de Formação e Aperfeiçoamento da Magistratura - ENFAM. Membro da Rede de Direitos FundamentaisREDIR, do Conselho Nacional de Justiça-CNJ, Brasília. Coordenador Científico do Núcleo de Pesquisa Judiciária, da Escola Nacional de Formação e Aperfeiçoamento da Magistratura - ENFAM, Brasília. Membro do Conselho Científico do Observatório da Justiça Brasileira. Coordenador da Rede de Observatórios do Direito à Verdade, Memória e Justiça nas Universidades brasileiras - Secretaria de Direitos Humanos da Presidência da República.

3 CARVAlHO, Orlando de. Para uma teoria geral da relação jurídica. Coimbra: Centelha, 1981

4 SOUZA, Rabindranath Capelo de. A Constituição e os direitos de Personalidade. In Estudos sobre a Constituição, coord. Jorge Miranda, Lisboa: Petrony, 1978, v. 2, p. 93.

5 Adverte o autor que posterior legislação sobre a matéria veio a dar mais coerência ao ponto, simplificando e esclarecendo uma série de conceitos importantes, em especial a Lei ${ }^{\circ} 196$, de 30/06/2003. Refere o autor que: L`adozione di un solo testo di rango legislativo, che prende il posto di un insieme di leggi e regolamenti, è inoltre più consono a disciplinare $i$ diritti e le libertà fondamentali tutelati dalla normativa privacy. $\mathrm{Nel}$ corso degli si è sviluppato sempre più il senso di dovere tutelare al meglio quello che è il diritto alla riservatezza del singolo individuo, ovvero il diritto del singolo a decidere autonomamente quando e con quali limiti possono essere diffuse informazioni riguardanti la propria persona. L'individuo non ha più un diritto assoluto di essere lasciato in pace, ma il diritto di conoscere il flusso di informazioni che lo riguardano: il diritto alla privacy acquista così una valenza diversa, rispetto all'originaria pretesa di escludere gli altri dalla propria vita privata, connotandosi come diritto di mantenere il controllo sulle informazioni relative alla propria persona e sull'uso che di esse viene da altri fatto. In PACE, Alessandro. Metodi interpretativi e costituzionalismo. Quaderni Costituzionali, Rivista Italiana di Diritto Costituzionale, n. 1, aprile 2001, p. 21. ISSN: 0392-6664.

6 Idem, p. 26

7 Idem.

8 Idem.

9 CARVALHO, Márcia Haidée Porto de. A defesa da honra e o direito à informação. Florianópolis: Letras Contemporâneas, 2002, p. 94. No caso da intimidade, parte da doutrina refere que ele pode ser subdividido em três outros: o direito a solidão, o direito ao sigilo sobre os dados íntimos, o direito de decidir enquanto centro divulgador de informações sobre se deve ou não tornar publico aquilo que pertence a sua intimidade.

${ }^{10}$ LUÑO, Antonio Henrique Pérez. Derechos Humanos, Estado de Derecho y Constitución. Madrid: Tecnos, 1999, p. 335.

${ }^{11}$ A doutrina brasileira tem se preocupado com esta discussão desde há muito, basta ver os textos de PONTES DE MIRANDA, Francisco Cavalcanti. Tratado de Direito Privado. Direito de Personalidade. Direito de Família. Rio de Janeiro: Borsoi, 1955; GOMES, Orlando. Introdução ao Direito Civil. Rio de Janeiro: Forense, 2000; FRANÇA, Rubens Limongi. Instituições de Direito Civil. São Paulo: Saraiva, 1999.
${ }^{12}$ FERRAZ JR., Tércio Sampaio. Sigilo de dados: o Direito à privacidade $e$ os limites à função fiscalizadora do Estado. In: <http://www. terciosampaioferrazjr.com.br/?q=/publicacoes-cientificas/28>, acesso em: 15/03/2014, p. 04.

${ }_{13}$ BARBOSA, Álvaro Antônio do Cabo. Direito à própria imagem. Aspectos fundamentais. São Paulo: Saraiva, 1989, p. 25.

14 JESUS, Damásio. E. de. Direito penal: parte especial: dos crimes contra a pessoa. Dos crimes contra o patrimônio. São Paulo: Saraiva, 2006. v. 2 , p. 189

15 TOURINHO FILHO, Fernando da Costa. Processo Penal. Vol. 4. São Paulo: Saraiva, 2007, p. 74. Dentre outros, BITENCOURT, Cezar Roberto. Código penal comentado. São Paulo: Saraiva, 2010, p. 537, rebate este argumento a partir da tese de ser irrelevante que o fato difamatório imputado seja falso ou verdadeiro, pois ninguém tem o direito de vilipendiar ninguém.

${ }^{16}$ Recurso Extraordinário no 215.984 , da relatoria do Min. Carlos Velloso, julgado em 04/07/2002, tendo como recorrente a atriz Cássia Kis e recorrido a empresa Ediouro S/A. Neste caso, o Tribunal de Justiça do Rio de Janeiro (onde foi processado o feito) indeferiu a pretensão da autora ora recorrente extraordinária, sob o argumento de que o uso de fotografias de uma pessoa, para publicação, sem a respectiva autorização, geraria apenas o direito à indenização por danos materiais, e não por danos morais.

17 É interessante notar, como já referi em outra oportunidade, que esta posição do STF evidencia bem que a unidade do direito e da decisão judicial é uma unidade de processo, essencialmente dialética e histórica, pois que se dá no plano fático, axiológico e normativo, concomitantemente. $\mathrm{Na}$ situação de um normativismo jurídico concreto ou integrante, a decisão judicial se transforma em norma e situação normada em um só ato de concreção. Ver meu texto. LEAL, Rogério Gesta. A Decisão Judicial: elementos teórico-constitutivos è efetivação pragmática dos Direitos Fundamentais. Chapecó: UNOESC, 2012, p. 119 e seguintes.

${ }^{18}$ CASTRO, Sandro. Il danno all 'immagine. Roma: Giappichelli Editore, 2013, p. 29.

19 Ver também o texto de LEEBAW, Bronwyn. Judging State-sponsored Violence, Imagining Political Change. New York: Cambridge University Press, 2012

${ }^{20}$ É de se lembrar que o Superior Tribunal de Justiça já teve oportunidade de decidir que há consentimento tácito de exposição e uso da imagem em cenário público a situação da prática de topless voluntário, no REsp. $\mathrm{n}^{\circ}$ 595600/SC, relatoria M. Cesar A. Rocha, $4^{\text {a }}$ Turma, julgado em 18/03/2004

${ }^{21}$ PROSPERI, Massimo. La tutela dell'immagine. Roma: Giappichelli Editore, 2012, p. 55 - grifo meu. Adverte ainda o autor que: Al di là di quanto si è detto sin qui, esiste un limite generale all'uso dell'immagine di una persona: tale uso non deve ledere l'onore, la reputazione o il decoro della persona di cui si utilizza l'immagine.

${ }^{22}$ In http://www.law.cornell.edu/supremecourt/, acessado em 31/01/2014.

${ }^{23}$ Como quer SILVA, Paulo Napoleão Nogueira da. Curso de direito constitucional. Rio de Janeiro: Forense, 2009, p. 539.

${ }^{24}$ Idem, p. 91. Ver meu texto LEAL, Rogério Gesta. O Estado-Juiz na Democracia Contemporânea: uma perspectiva procedimentalista. Porto Alegre: Livraria do Advogado, 2007.

25 Ver o texto de MENGONI, Luiggi. Ermeneutica e dogmatica giuridica. Milano: Giuffrè, 2006, p. 29 e seguintes. Ainda agrega o autor aqui outras diferenças, seguindo o raciocínio de Alexy, tais como: (1) $i$ principi sono soggetti ad eccezioni implicite, non chiaramente determinate in anticipo (sono norme defettibili), e quindi sono ragioni non conclusive, applicabili solo prima facie, poiché la loro applicazione può essere differita una volta considerati tutti i fattori rilevanti; di contro, le regole sarebbero soggette ad applicazione categorica, tutto-o-niente, una volta verificatesi le circostanze fattuali previste nella fattispecie; (2) i principio sono "mandati di ottimizzazione", cioè prescrivono il perseguimento di un certo obiettivo, valore ecc., nella maggior misura possibile a seconda delle concrete possibilità fattuali e normative. 
${ }^{26}$ Como diz SCHAUER, Francisco. Le regole del gioco. Un'analisi filosofica delle decisioni prese secondo regole nel diritto e nella vita quotidiana. Bologna: Il Mulino, 2009, p. 56: Così, un principio costituzionale ha un peso astratto maggiore rispetto ad un principio legislativo, un principio legislativo ha un peso astratto maggiore rispetto ad un principio consuetudinário. É claro que o autor adverte que este fator não é matemático, eis que entre os princípios pode haver tensões que demandam soluções múltiplas.

27 Un secondo ordine di fattori per determinare il peso di una norma è relativo alle gerarchie assiologiche accreditate nell'ordinamento elo nelle pratiche degli interpreti: in questo senso, il peso di una norma sarà funzione della sua relativa prossimità (strumentalità, implicazione, ecc.) rispetto agli ideali etico-politici che gli interpreti ritengono accolti nell'ordinamento giuridico di riferimento, o nel sotto-sistema rilevante (ad es., il diritto privato, il diritto penale, oppure il diritto dei contratti, ecc.). Idem.

${ }^{28}$ Un terzo ordine di fattori per determinare il peso di una norma è relativo alle circostanze rilevanti nel contesto di applicazione della norma stessa, circostanze fattuali (la possibilità concreta di attuazione della norma in base alle risorse disponibili) e normative (l'esistenza di altre norme concorrenti o confliggenti). Idem.

29 ALEXY, Robert. A theory of legal argumentation: the theory of rational discourse as theory of legal justification. In Ratio Juris,v. 37. New York: Hammel, 2010, p. 30. Os exemplos que o autor dá para tal afirmação são fortes, ao dizer que: Thus, it can be very doubtful whether a certain statement is an expression of one's opinion - protected by the freedom of speech, or whether a certain activity is an exercise of religion, or whether a certain valuable advantage counts as property - protected by the constitution.

30 ALEXY, Robert. Teoria da Argumentação Jurídica: a teoria do discurso racional como teoria da justificação jurídica. São Paulo: Landy, 2001, p. 21.

31 ALEXY, Robert. The Construction of Constitutional Rights. Op. cit., p. 09 .

32 É interessante como Alexy associa este sub-princípio à lógica do Ótimo de Pareto: the subject of the first two sub-principles, the sub-principle of suitability and necessity, is optimization relative to the factual possibilities. In this respect, they are concerned with the question of whether the factual possibilities allow for the avoidance of costs to constitutional rights without bringing about costs contrary to the aims of the legislator. The issue, in other words, is Pareto-optimality. Op. cit., p. 10.

33 The basic idea of optimization relative to the legal possibilities at hand can be expressed by a rule that might be called the "Law of Balancing." A statement of this rule runs as follows: "The greater the degree of nonsatisfaction of, or detriment to, one principle, the greater must be the importance of satisfying the other". Idem, p. 11. Ver também ALEXY, Robert. Teoría de los Derechos Fundamentales. Madrid: Centros de Estudios Constitucionales, 2000, p. 112.

${ }^{34}$ MANIACI, Giorgio. Note sulla teoria del bilanciamento di Robert Alexy. I Rivista Diritto\&Questioni Pubbliche, v. 2. agosto de 2002. Palermo: Università degli Studi di Palermo, 2002, p. 03. Ainda lembra o autor que: In termini guastiniani la regola che determina la precedenza di un principio sull'altro sarebbe una 'gerarchia assiologica móbile'.

35 ALEXY, Robert. The Construction of Constitutional Rights. Op. cit., p. 05.

36 Afasto-me, assim, dos que defendem existir uma hierarquia material das normas constitucionais - ou de Direitos Fundamentais Preferenciais em Abstrato -, aproximando-me mais da ideia de que é o devido processo legal substantivo que autoriza controles de razoabilidade dos atos capazes de operarem restrição aos Direitos Fundamentais.

37 CHEQUER, Cláudio. A liberdade de expressão como Direito Fundamental preferencial prima facie. Rio de Janeiro: Lúmen Júris, 2011, p. 68

${ }^{38}$ A partir de CANARIS, Wilhelm Canaris. Pensamento sistemático e conceito de sistema na ciência do direito. Lisboa: Fundação Calouste Gulbenkian, 1996, p. 83, a ideia de sistema se sustenta em razão de alguns pressupostos: (1) necessidade de um mínimo de racionalidade na dogmática; (2) da identificação das instituições com sistemas de ações e de interações, o do próprio direito como um sistema de comunicações: (3) o do apoio sociológico da estruturação jurídica; (4) o do tipo do pensamento dos juristas.

39 CHEQUER, Cláudio. A liberdade de expressão como Direito Fundamental preferencial prima facie. Op. cit., p. 68. Lembra o autor que a Corte Europeia de Direitos Humanos condenou o Estado Austríaco pelo fato de que um Tribunal doméstico seu condenara jornalista por críticas duras feitas ao então chanceler da Áustria, Bruno Kreisky, por ter ele sido benevolente para com os nazistas durante a Segunda Guerra Mundial, violando, assim, o direito fundamental à expressão e informação.

${ }^{40}$ FERRAZ JR., Tércio Sampaio. Sigilo de dados: o Direito à privacidade e os limites à função fiscalizadora do Estado. Op. cit., p. 03.

${ }^{41}$ ALEXY, Robert. The Construction of Constitutional Rights. In Law \& Ethics of Human Rights, Volume 4, Issue 1. Article 2. Berkeley: Berkeley Electronic Press, 2010, p. 09. Estou consciente das objeções que a Teoria da Argumentação Jurídica tem sofrido ex vi os textos de: POSCHER, Ralf. Einsichten, Irrtümer und Selbstmißverständnisse der Prinzipientheorie. In Die Prinzipientheorie der Grundrechte: studien zur grundrechtstheorie Robert Alexys. 59, 65, 70 (Jan-R. Sieckmann ed., 2007); e o de KLEMENT, Jan Henrik. Vom Nutzen einer Theorie, die alles erklärt, 63. Juristenzeitung 756, 760 (2008); HABERMAS, Jürgen. Between Facts and Norms: contributions to a discourse theory of law and democracy. William Rehg trans., Polity Press, 1996; e SCHLINK, Bernhard. Der Grundsatz der Verhältnismäßigkeit, in Festschrift 50 Jahre Bundesverfassungsgericht 445, 460 (Peter Badura \& Horst Dreier eds., 2001); BÖCKENFÖRDE, Ernst-Wolfgang. Staat, Verfassung, Demokratie 190 (1991). Cita o autor aqui o trabalho de JESTAEDT, Matthias. Die Abwägungslehre - ihre Stärken und ihre Schwächen. In Staat im Wort: Festschrift für Josef Isensee 253, 260, 262-63, 275 (Otto Depenheuer, Markus Heintzen, Matthias Jestaedt, \& Peter Axer eds., 2007). Não tenho tempo de aprofundar tais argumentos aqui, mas vale a pena ver as considerações que Alexy faz sobre seus críticos no texto sob comento.

${ }^{42}$ É interessante como Alexy associa este subprincípio à lógica do Ótimo de Pareto: the subject of the first two sub-principles, the sub-principle of suitability and necessity, is optimization relative to the factual possibilities. In this respect, they are concerned with the question of whether the factual possibilities allow for the avoidance of costs to constitutional rights without bringing about costs contrary to the aims of the legislator. The issue, in other words, is Pareto-optimality. Op. cit. p. 10 .

${ }^{43}$ The basic idea of optimization relative to the legal possibilities at hand can be expressed by a rule that might be called the "Law of Balancing." A statement of this rule runs as follows: "The greater the degree of nonsatisfaction of, or detriment to, one principle, the greater must be the importance of satisfying the other". Idem, p. 11. Ver também ALEXY, Robert. Teoría de los Derechos Fundamentales. Madrid: Centros de Estudios Constitucionales, 2000, p. 112.

44 Aprofundei este tema no texto LEAL, Rogério Gesta. A Decisão Judicial: elementos teórico-constitutivos à efetivação pragmática dos Direitos Fundamentais. Chapecó: Unoesc, 2012.

${ }^{45}$ MANIACI, Giorgio. Note sulla teoria del bilanciamento di Robert Alexy. In Rivista Diritto\&questioni pubbliche, v. 2, agosto 2002. Palermo: Università degli Studi di Palermo, 2002, p. 03. Ainda lembra o autor que: In termini guastiniani la regola che determina la precedenza di un principio sull'altro sarebbe una 'gerarchia assiologica móbile'.

46 ALEXY, Robert. The Construction of Constitutional Rights. Op. cit., p. 05.

47 ALEXY, Robert. A argumentação jurídica como discurso racional. In: TEIXEIRA, Anderson Vichinkeski; OLIVEIRA, Elton Somensi de Oliveira (Orgs.). Correntes Contemporâneas do Pensamento Jurídico. São Paulo: Manole, 2010, p. 04. Já referi anteriormente, com Habermas, que o pensamento crítico dialético capta a necessidade da reflexão que a hermenêutica filosófica gadameriana não leva até as últimas consequências, reconhecendo a importância da tradição e da autoridade, porém, problematizando-as a partir do enfrentamento dos seus postulados instituídos, para superá-los no movimento dialético das interlocuções tensas e conflitantes que a comunicação (o mais possível e criticamente - princípio regulativo) não coatada possa desenvolver.

${ }^{48}$ Idem. Aduz em seguida Alexy que: A justeza de uma interpretação só pode ser provada quando forem determinadas as razóes em seu favor e rejeitados os motivos que a ela se opõem. Portanto, a frase "interpretação é argumentação" torna-se verdade.(p. 05). É interessante que este debate inclusive se estende para o significado mesmo de norma jurídica, lembrando aqui GUASTINI, Ricardo. Le fonti del diritto e l'interpretazione. Milano: Giuffrè, 1993, p. 32: Si è assunta dunque piena consapevolezza della distinzione concettuale tra la "disposizione", intesa come il testo scritto della legge e la "norma", come significato che, attraverso l'interpretazione, viene attribuito al testo. La norma cioè non è data dal legislatore, né trovata dall'interprete, ma costantemente ricreata nel momento applicativo.

49 Para Alexy: o discurso legal pode ser distinguido do discurso prático geral pelo fato de que o primeiro, em resumo, é restrito em seu objetivo 
pelo estatuto, pelos precedentes e pela dogmática legal e - no caso dos procedimentos judiciais -, pela legislação e regulamentações processuais. ALEXY, Robert. A argumentação jurídica como discurso racional. Op. cit., p. 29. E por que tais restrições? Pelo reconhecimento: (a) do amplo alcance do que é meramente possível discursivamente; (b) da natureza experimental de quaisquer conclusões; (c) da necessidade de resolver muitas questões prática num espaço de tempo curto.

${ }^{50}$ Novamente Schauer chama a atenção para o fato de que the openended premises of a proportionality argument are admissible in legal discourse generally, and we see such open-ended selection of premises, factors, and considerations not only in proportionality arguments, but also in common law adjudication. In SCHAUER, Frederick. Balancing, Subsumption, and the Constraining Role of Legal Text. Op. cit., p. 11. Ver também o excelente texto do autor: SCHAUER, Frederick. The nature of customary law: legal, historical and philosophical perspectives. New York: Amanda Perreau-Saussine \& James Bernard Murphy eds., 2007.

${ }^{51}$ ALEXY, Robert. A argumentação jurídica como discurso racional. Op. cit., p. 30.

52 Ação Penal n 307-3-DF, onde figuravam como autor o Ministério Público Federal e como réus o Ex-presidente da República, Fernando Affonso Collor de Mello, Paulo César Farias. STF, Ação Penal no 307-3- DF, Plenário, Rel. Min. Ilmar Galvão, DJU, 13/10/95; in Revista Trimestral de Jurisprudência do Supremo Tribunal Federal 162/03-340. Ver o texto de BARROS, Suzana de Toledo. O principio da proporcionalidade e o controle de constitucionalidade das leis restritivas de direitos fundamentais. Brasília: Brasília Jurídica, 2000.

53 AVÓLIO, Luiz Francisco Torquato. Provas ilícitas: interceptações telefônicas clandestinas. São Paulo: Revista dos Tribunais. 2003, p. 45. Ver também o texto de GOMES FILHO, Antonio Magalhães. Direito à prova no processo penal. São Paulo: RT, 1997.

${ }^{54}$ STF, MS n. 23.452/RJ, Plenário, Rel. Min. Celso de Mello, DJU 12/05/2000. Em oportunidade ainda anterior, referiu a Suprema Corte que: É licita a gravação de conversa telefônica feita por um dos interlocutores, ou com sua autorização, sem ciência do outro, quando há investida criminosa deste último. É inconsciente e fere o senso comum falar-se em violação do direito à privacidade quando o interlocutor grava diálogo com sequestradores, estelionatários ou qualquer tipo de chantagista STF, HC n. 75.337-8/RJ, Plenário, Rel. Min. Nelson Jobim, DJU 25/09/1998.

55 Mandado de Segurança $n^{\circ} 24.369$, do STF. Grifo meu. Da mesma maneira as decisões: Recurso Ordinário em Mandado de Segurança $\mathrm{n}^{\circ} 4.435$, do STJ; Recurso Ordinário em Mandado de Segurança ${ }^{\circ}$ 1.278, do STJ; Recurso em Habeas Corpus $\mathrm{n}^{\circ} 7.329$, do STJ; Recurso em Habeas Corpus $n^{\circ} 7.363$, do STJ. A forte doutrina contrária a este ponto, basta ver GRINOVEER, Ada Pellegrini. Liberdades públicas e processo penal: as interceptações telefônicas. São Paulo: Revista dos Tribunais, 1982 e GRINOVER, Ada Pellegrine; FERNANDES, Antonio Scaranze; GOMES FILHO, Antonio Magalhães. As nulidades no processo penal. São Paulo: Revista dos Tribunais, 2001. Neste texto os autores afirmam com todas as letras que: chegou-se a conclusão de que a prova obtida por meios ilícitos deve ser banida do processo, por mais relevantes que sejam os fatos por ela apurados, uma vê que se subsume ela ao conceito de inconstitucionalidade, por vulnerar normas ou princípios constitucionais - como, por exemplo, a intimidade, o sigilo das comunicações, a inviolabilidade do domicílio, a própria integridade e dignidade da pessoa. (p. 135). Não tenho tempo de aprofundar este debate aqui, tampouco o que envolve a questão das provas ilícitas.

56 STJ, HC n. 7.216/SP, $5^{\text {a }}$ Turma, Rel. Min. Edson Vidigal, CJU $25 / 05 / 1998$

${ }^{57}$ STF, HC 70.814-5, rel. Min. Celso de Mello, DJU, 24 jun. 1994, p. 16649

58 CAPEZ, Fernando. Curso de Processo Penal. São Paulo: Saraiva, 2008, p. 37. Na mesma direção GRINOVER, Ada Pellegrine; FERNANDES, Antonio Scaranze; GOMES FILHO, Antonio Magalhães. As nulidades no processo penal. Op.cit., asseverando que a utilização de uma prova ilícita em benefício do acusado, ainda que colhida com infringência a Direitos Fundamentais seus ou de terceiros se vê legitimada em face da ampla defesa e do princípio do favor rei.

59 SCHAUER, Frederick. Balancing, Subsumption, and the Constraining Role of Legal Text. Op. cit., p. 07.

${ }^{60} \mathrm{E}$ neste ponto Alexy é muito claro, pois aduz que: Calculable measurements by way of a continuum of points between 0 and 1 cannot have any application. Idem, p. 14. Vai na mesma direção o questionamento de TARELLO, Giovanni. Interpretazione della legge. Roma: Giuffrè, 2010, p. 61: La questione è dunque comprendere se il ragionamento dell'interprete sia razionale o se piuttosto si determini secondo scelte legate all'opportunità del caso. La sentenza esprime una scelta politica del giudice? La decisione dipende da un sistema di norme predefinito o è soluzione di giustizia individuata in base ai pregiudizi dei soggetti chiamati a decidere?

61 ALEXY, Robert. Os Direitos Fundamentais e a Democracia no Paradigma Procedimental do Direito de Jürgen Habermas. In: FRANKENBERG, Günter \& MOREIRA, Luiz. Jürgen Habermas: 80 anos. Rio de Janeiro: Lúmen Júris, 2009, p. 121.

${ }^{62}$ Esta preocupação é também institucionalista (além de procedimental), na medida em que reconhece a outros espaços institucionais iguais competências à deliberação pública sobre aspectos normativos da sociedade civil. Lembro-me das reflexões de GRIFFIN, Stephen. American Constitutionalism: from theory to politics. Princeton: Princeton University Press, 1996, ao sustentar que o Judiciário não tem supremacia exclusiva no processo de interpretação constitucional, uma vez que todos os órgãos constitucionais são responsáveis pela efetivação e interpretação do sistema jurídico (notadamente o constitucional).

${ }^{63}$ ANDRONICO, Alberto. Ermeneutica e diritto da Wilhelm Dilthey ed Emilio Betti. In Spicchi di Novecento, a cura di Bruno Montanari. Roma: Giappichelli, 2008, p. 49. Refere ainda o autor: Posto dunque che il ragionamento che viene seguito per l'applicazione del diritto non è riconducibile alla sola logica formale, ma è scelta da parte del giudice di una tra le varie soluzioni possibili, posto ancora che il diritto non è l'insieme delle norme date dal sovrano, né l'insieme delle decisioni dei tribunali, ma ordine normativo sempre nell'atto di positivizzarsi, la questione che si pone è quella di individuare il reale fondamento della decisione del giudice.

${ }^{64}$ Idem.

${ }^{65}$ Habermas entende, aqui, que conceber os princípios informativos do sistema normativo como mandados de otimização permitiria análises envolvendo custos e vantagens, e isto, sob o prisma normativo, levaria a uma restringibilidade dos bens que protege em face de outros bens, mesmo que coletivos. Em outras palavras: Uma jurisprudencia orientada por princípios precisa definir qual pretensão e qual ação deve ser exigida num determinado conflito - e não arbitrar sobre o equilibrio de bens ou sobre o relacionamento entre valores. HABERMAS, Jürgen. Direito e Democracia: entre faticidade e validade. Vol. I. Op. cit., p. 323.

${ }^{66}$ Habermas é explícito ao defender que: Principios e regras não têm estrutura teleológica. Eles não podem ser entendidos como preceitos de otimização - conforme é sugerido pela "ponderação de bens" nas demais doutrinas metodológicas -, porque isso suprimiria seu sentido de validade deontológica. Idem, p. 258. Argúi o autor que: No desenrolar dos casos, estabelece-se entre os princípios uma ordem transitiva, sem que isso arranhe sua validade, sem explicar pragmaticamente, no entanto, o que entende por ordem transitiva, até porque, no ponto, parece concordar com Dworkin em relação à tese de que: no conflito entre princípios, não se faz necessária uma decisão do tipo "tudo ou nada". É certo que um determinado princípio goza de primazia, porém não a ponto de anular a validade dos princípios que cedem o lugar. Um princípio passa à frente do outro, conforme o caso a ser decidido. (p. 259).

${ }^{67}$ CELANO, Bernardo. Dialettica della giustificazione pratica. Torino: Giappichelli, 2008, p. 51.

${ }^{68}$ CARNAUBA, Maria Cecília Pontes. Prova Ilícita. São Paulo: Saraiva, 2000, p. 22 